\title{
ASPECTUL MISIONAR AL MUZICII RELIGIOASE
}

Dragoş-Ioan Șuşman *

\begin{abstract}
Missionary aspect of religious music. One of the most efficient methods of drawing the believers closer to the holy service is engaging them in singing the holy hymns. This method has been successfully applied since the dawn of Christianity. On the other hand, when it was neglected, the consequences did not fail to appear: the believers grew less interested in the public divine worship, the community spirit weakened and so, the believers grew more vulnerable to the heterodox influences. These consequences were, and still are felt in the life of the Romanian Orthodox Church. After several decades when the Romanian Orthodox people were forced to live apart from the Church, they finally regained the freedom to manifest their faith. But this fact didn't actually mean the rebirth of the religious life that existed in our country before the communist regime. In order to regain the authentic Christian life, it is necessary to restore the proper Christian environment and, first of all, the liturgical atmosphere. All things being considered, we can not underestimate the importance of religious music and its role in creating this mystical liturgical atmosphere.
\end{abstract}

Keywords: mission, music, divine service, tradition, community.

\section{Preliminarii}

Dacă participăm la programul liturgic complet al unei zile, putem să observăm că în desfăşurarea acestuia muzica este nelipsită. Oprindu-ne, de pildă, la ciclul celor şapte Laude, descoperim o armonioasă împletire între cuvântul citit şi cel cântat. Această alternanță poate fi sesizată şi în rânduiala Sfintei Liturghii, doar că aici muzica dobândeşte o pondere mai mare. Este firesc să ne

* PhD, Teacher at "Lucian Blaga" Secondary School, Sebeş, Alba County. 
întrebăm de ce în această slujbă muzica ocupă un loc atât de important. Motivul cel mai evident care generează această situație este însăşi structura Sfintei Liturghii, care are la bază un dialog continuu între cler şi credincioşi. Or, pentru ca acest dialog să poată fi realizat în condiții optime, este necesară o perfectă sincronizare între cei care dialoghează. Aici intervine muzica, care reuşeşte să facă din mii de glasuri unul singur.

Nicicând nu s-a realizat mai deplin participarea activă a credincioşilor la Sfânta Liturghie, ca în Biserica primelor veacuri. Această participare se concretiza în mai multe acte. Mai întâi credincioşii aduceau materia de jertfă, adică darurile de pâine şi vin pentru Sfânta Euharistie. Posibilitatea de a aduce ofranda la Sfântul Altar era nu numai o datorie, ci şi un drept de onoare pentru fiecare creştin.

În al doilea rând, vechii creştini participau efectiv la Sfânta Liturghie prin rolul activ pe care îl aveau în executarea răspunsurilor din cursul serviciului liturgic. Rânduiala Sfintei Liturghii din primele trei-patru secole, aşa cum o descriu cele mai vechi mărturii şi documente liturgice, se înfățişează ca un continuu dialog între proestosul - episcop sau preot şi diacon, pe de o parte - şi popor, pe de altă parte. Instituțiile cântărețului şi citețului, care se interpun între liturghisitori şi credincioşi, apar ceva mai târziu, având la început un rol destul de modest şi de limitat. La aceasta contribuia şi faptul că rânduiala Sfintei Liturghii nu era pe atunci aşa de dezvoltată şi de complicată ca acum. Toate rugăciunile pe care preotul le citeşte astăzi în taină erau rostite în întregime cu glas tare, ca şi ecteniile. Credincioşii, care le puteau urmări astfel cu atenția cuvenită, se asociau toți cu un singur glas prin răspunsuri care erau scurte şi puține la număr, fie confirmând conținutul rugăciunilor prin încheierea $A m i n$, fie dând urmare îndemnului la rugăciune cu formulele Doamne miluieşte sau Dă, Doamne.

În al treilea rând, actul cel mai de seamă în care se exterioriza şi cu care culmina în vechime participarea activă a poporului la Sfânta Liturghie era împărtăşirea cu Sfintele Taine. Această împărtăşire era generală şi frecventă, adică se împărtăşeau toți credincioşii la fiecare Sfântă Liturghie. 
Efectul sau rezultatul cel mai vizibil pe plan social al acestei intense trăiri a Sfintei Liturghii era acea unitate şi strânsă solidaritate de duh şi de simțire care îi lega între ei pe toți membrii Bisericii primare, unitate care se realiza în chip sensibil mai ales în adunările de cult.

Începând din veacul al şaselea se observă o oarecare stagnare în viața liturgică a Bisericii, urmată apoi de o decadență care merge crescând până în zilele noastre. Primul ei semn este slăbirea spiritului eclesiologic sau comunitar, spirit care constituia titlul de glorie al Bisericii ecumenice de odinioară. Cauza principală a acestei situaţii este dispariţia împărtăşirii generale şi regulate de până atunci.

Concomitent cu slăbirea râvnei pentru împărtăşire, scade şi interesul credincioşilor față de Sfânta Liturghie în general. La acest proces a contribuit şi dezvoltarea treptată a rânduielii acestei slujbe. Începând din secolul al V-lea şi până în secolul al XIV-lea, rânduiala simplă şi uşor de urmărit a liturghiei creştine din epoca uniformităţii liturgice (primele trei secole creştine) se dezvoltă şi se complică din ce în ce mai mult prin adăugarea succesivă a unor noi piese, imne şi rituri sau ceremonii. Pătrunderea progresivă a imnelor noi, de inspirație creştină, în rânduiala Liturghiei, imne care nu mai puteau fi executate în chip ideal de totalitatea credincioşilor prezenți, a făcut necesară extinderea atribuțiilor cântărețului, stranei sau corului, în dauna poporului. Deşi Liturghierul continuă să pună răspunsurile liturgice pe seama poporului, în fapt ele devin apanajul uneori exclusiv al cântărețului, care cântă în numele şi în locul credincioşilor. Iată cum poporul rămâne astfel străin şi pasiv chiar față de partea externă şi secundară a serviciului liturgic, pe care o formează imnele sau răspunsurile stranei.

În aceste condiții este firesc să ne întrebăm ce măsuri ar trebui luate sau ce mijloace şi metode s-ar putea folosi pentru a aduce poporul în biserică şi pentru a-i susține atenția şi interesul în timpul sfintelor slujbe.

Legile psihologiei demonstrează că în orice împrejurare e preferabil să fii activ, să ai un rol de îndeplinit, decât să fii indiferent, dezinteresat şi inactiv. Slujbele noastre tocmai de aceea par lungi şi obositoare pentru credincioşi, pentru că aceştia asistă la ele în chip 
pasiv. Prin urmare, atitudinea credincioşilor nu trebuie să fie de pasivitate, ci de participare integrală, atât cu trupul cât şi cu sufletul. $\mathrm{Cu}$ sufletul însoțindu-l pe preot - adică mulțumind, rugându-se sau slăvind pe Dumnezeu - iar cu trupul imitând pe preot, adică urmărind cu ochii desfăşurarea slujbei, asociindu-se cu buzele la cântarea şi rugăciunile liturgice şi adaptându-şi ținuta exterioară a trupului după caracterul momentelor respective: stând drept sau îngenunchiind, făcând semnul Sfintei Cruci ş.a.m.d.

\section{Metode concrete de realizare a cântării în comun}

Încurajarea, cultivarea şi organizarea cântării în comun a poporului în biserică este unul dintre mijloacele pastorale cele mai eficace pentru întărirea adeziunii creştinilor față de cultul divinpublic. ${ }^{1}$ Privită la început, pe nedrept, ca o manifestare cu caracter protestant sau sectar, cântarea în comun a credincioşilor în biserică sa impus, în cele din urmă, tocmai ca o armă de luptă împotriva prozelitismului sectar. $^{2}$

În secolele patru şi cinci cântarea în comun a poporului a fost larg utilizată, sub forma psalmodiei sau a cântării antifonice, ca o armă de luptă împotriva ereziilor. Aşa au utilizat-o: Sfântul Efrem Sirul la Edessa (împotriva lui Bardesane şi Armoniu), preoții Diodor şi Flavian la Antiohia (împotriva arienilor), Sfântul Ambrozie cel Mare la Milan şi Sfântul Ioan Gură de Aur la Constantinopol. Prin urmare, departe de a fi o inovaţie cu caracter sectar sau cu aspect confesional, cântarea în comun a poporului nu e decât o revenire la tradiția Bisericii primare. ${ }^{3}$

${ }^{1}$ Nicolae Lungu, Cântarea în comun a poporului în biserică, în „Studii Teologice", III (1951), nr. 1-2, p. 26.

${ }^{2}$ „Nu este nevoie ca preotul să se războiască cu cei ce caută să-i dezbine turma. Să fie lăsați numai credincioşii să învețe cântările Sfintei Liturghii, şi ei inşişi vor aduce la biserică pe cei rătăcițī". Cf. Antim Târgovişteanul, Despre cântarea credincioşilor în biserică, în „Biserica Ortodoxă Română”, LXXI (1953), nr. 11-12, p. 119.

${ }^{3}$ Vezi Petre Vintilescu, Despre poezia imnografică din cărțile de ritual şi cântarea bisericească, ediția a II-a, Cluj-Napoca, Edit. Renaşterea, 2005, pp. 24-34. 
Repertoriul care va fi abordat în cadrul cântării în comun a credincioşilor în biserică este recomandabil să se bazeze pe cântările bisericeşti tradiționale, adică pe răspunsurile sau părțile din rânduiala sfintelor slujbe înscrise în cărțile de ritual pe seama cântăreților sau a corului. Vor fi evitate cântările extra-liturgice, de proveniență incertă, eterodoxă sau sectară, cu texte şi melodii adesea profane sau cu totul străine de spiritul doctrinei ortodoxe şi al muzicii noastre bisericeşti. Dacă astfel de cântări pot fi binevenite în anumite adunări extra-liturgice, care au loc în afara incintei bisericii, ele trebuiesc selecționate cu mai multă grijă de cei responsabili, atunci când e vorba să fie cântate în biserică. Aici pot fi înlocuite foarte bine cu minunatele imne, tropare şi condace, sedelne şi podobii, svetilne şi chinonice, care alcătuiesc repertoriul atât de bogat şi de variat al muzicii noastre liturgice. ${ }^{4}$

Mijloacele şi metodele de lucru pentru organizarea cântării în comun a poporului în biserică pot fi adaptate la împrejurările, nevoile şi posibilităţile fiecărei parohii. $\mathrm{Nu}$ este nevoie - şi nici nu este posibil - să fie instruiți în cântarea bisericească toți credincioşii care vin la sfintele slujbe, ci numai o parte dintre ei, de preferință copiii, tinerii şi femeile cu voce şi ureche muzicală mai bună. Aceştia îi vor atrage pe toți ceilalți spre cântare, astfel că cel puțin o parte dintre cei prezenți la slujbă vor slăvi pe Dumnezeu cu o gură şi cu o inimă. Instruirea muzicală a credincioşilor poate fi realizată fie de către preot, fie de cântăreț, fie de un alt membru al parohiei cu cultură muzicală şi cu râvnă pentru biserică. În privința modalității de execuție a cântării bisericeşti, se poate opta atât pentru cântarea omofonă, cât şi pentru forma mai pretențioasă a cântării polifonice armonizate, adică în coruri pe două, trei sau patru voci.

${ }^{4}, N u$ introducerea în biserică [...] a unor cântări de influență protestantă sau sectară, străine de duhul autentic ortodox, sunt căile pentru a atrage tineretul la biserică, ci o intensă şi susținută lucrare de educație şi instruire religioasă. Biserica Ortodoxă nu are nevoie de asemenea mijloace, când ea are o muzică atât de caldă şi de apropiată sufletului omenesc, creând cea mai propice atmosferă de rugăciune", în Nicolae D. Necula, Tradiție şi înnoire în slujirea liturgică, Galați, Edit. Episcopiei Dunării de Jos, 1996, p. 19. 
Ca metodă, se va începe cu cântările mai scurte, mai simple şi mai uşor de învățat ca: Sfinte Dumnezeule, Tatăl Nostru, răspunsurile de la ectenii şi altele. Se va continua apoi cu cele mai lungi şi mai grele, cum ar fi Heruvicul şi Axionul. După ce se vor învăța cântările Sfintei Liturghii, se va trece la cântările unor slujbe mai frecvente şi cu rânduială fixă, cum ar fi Parastasul sau Cununia.

Cântarea în comun a credincioşilor reprezintă nu numai una dintre formele principale de participare activă a poporului la cultul divin, ci şi un admirabil instrument pedagogic-educativ şi o excelentă metodă misionară. Iată ce spune Părintele Petre Vintilescu în acest sens:

„Puterea de atracție şi de înrâurire a cântării religioase în general şi a celei liturgice în special, valoarea ei catehetică şi educativă fac din ea unul dintre cele mai eficace mijloace pastorale pentru aducerea poporului în biserică... Neîntrecuta bogăție doctrinară şi celelalte virtuți intrinsece ale imnelor ortodoxe, fac ca biserica să devină, prin cântarea credincioşilor în comun, nu numai un templu al credinței, ci şi o şcoală activă de emulație în pietate. Este înălţător să participi la Sfânta Liturghie, într-o biserică în care poporul se uneşte într-o gură şi o inimă prin cântare şi să simţi animaţia cucernică, ce se transmite tuturor, de la unul la altul, dar mai cu seamă de la grupul format la strană în jurul cântărețului odată cu începutul Liturghiei... Forma unisonică şi exercitarea cântării la strană de către credincioşi neprofesionişti îmbie şi atrage în albia ei şi pe ceilalți”. 5

Părintele Petre Vintilescu evidenţiază şi binefacerile dobândite în urma practicării cântării în comun:

„Două mari câş̧iguri pot decurge în chip natural pe plan pastoral din cultivarea cântării liturgice în comun: trezirea şi întreținerea în primul rând a conştiinței de comunitate, atât de fundamentală şi de esențială pentru viața religioasă a Bisericii noastre Ortodoxe. În al doilea rând, se organizează, prin participarea activă la viața liturgică, acea elită religioasă a

5 Petre Vintilescu, apud, Ene Branişte, Participarea la liturghie şi metodele pentru realizarea ei, în „Studii Teologice”, nr. 7-8/1949, pp. 623-624. 
parohiei, atât de necesară în acțiunea pastorală, ca aluatul menit să dospească toată frământătura (Cf. Mt. 13, 33)"”. ${ }^{6}$

Iată de ce, cultivarea şi organizarea cântării în comun a poporului în biserică se recomandă de la sine ca una dintre cele dintâi metode de utilizat pentru realizarea participării active a poporului la Sfânta Liturghie şi la cultul divin public în general. Aplicarea acestei metode ridică însă o problemă de ordin practic: încurajarea şi generalizarea cântării în comun a poporului în biserică înseamnă oare înlocuirea totală şi definitivă a cântărețului bisericesc sau suprimarea funcției acestuia? Pentru a putea răspunde la această întrebare sunt necesare câteva precizări în legătură cu locul şi rolul cântăreților în biserică.

Instituţia cântăreților sau a psalților a luat naştere atunci când, din cauza dezvoltării crescânde a cultului, a început să se simtă mai adânc nevoia disciplinării şi a organizării cântării religioase. Ei erau meniţi, nu să înlocuiască pe credincioşi în executarea cântării rituale, ci să-i ajute, să-i reprezinte, să-i instruiască şi să-i conducă, în calitatea lor de profesionişti şi responsabili ai cântării bisericeşti. În Biserica de Răsărit, ei au încetat de timpuriu să mai facă parte din rândul clericilor inferiori, rămânând în rândul laicilor.

Rolul şi importanța cântăreților bisericeşti a crescut cu timpul în defavoarea participării active a credincioşilor la cântarea religioasă. Acest fapt s-a datorat, pe de o parte, introducerii în cult a noilor producții ale poeziei imnografice (tropare, condace, canoane), iar, pe de altă parte, sistematizării cântărilor prin gruparea lor pe cele opt moduri de cântare (ehuri sau glasuri). Aceste procese au dus la complicarea cântării liturgice. Deoarece nu toată lumea îşi putea însuşi această tehnică pretenţioasă a muzicii bisericeşti, ea a fost lăsată, cu timpul, pe seama cântăreților de strană cu pregătire anume, mai ales la slujbele în rânduiala cărora au fost încadrate de preferință noile cântări (Vecernia şi Utrenia). Împrejurările vitrege în care s-a desfăşurat viaţa religioasă a popoarelor ortodoxe după căderea succesivă sub jugul robiei turceşti, au redus din ce în ce mai mult

${ }^{6}$ Ibidem, p. 624. 
participarea credincioşilor chiar la răspunsurile din slujba Sfintei Liturghii. În Biserica Ortodoxă Română, participarea poporului la cântarea bisericească nu a mai fost posibilă după introducerea în cult a limbii slave vechi, pe care credincioşii nu o cunoşteau. În virtutea tradiției, situația aceasta s-a menţinut, din nefericire, chiar şi după ce limba slavă a fost înlocuită cu cea română, prin traducerea în limba română a cărților de slujbă.

Prin urmare, lărgirea drepturilor fireşti ale poporului în executarea răspunsurilor liturgice nu înseamnă nicidecum scoaterea din uz a cântăreților, ci cel mult, o restrângere sau o limitare a rolului lor actual. Fiindcă oricât de intensă şi de largă ar fi participarea activă a poporului la cultul divin public, în materie de cântare ea se reduce efectiv la unele slujbe mai frecvente şi cu rânduială fixă, precum Sfânta Liturghie, Botezul, Cununia, Parastasul şi Înmormântarea. Rămân însă destule slujbe, precum Vecernia şi Utrenia, a căror rânduială mai complicată, cu cântări şi piese variabile, nu o cunoaşte decât cântărețul de profesie. Bogata lor imnologie nu poate fi executată corect, din punctul de vedere al melodiei, decât de oameni cu pregătirea şi competența muzicală necesară, pe care o posedă numai cântărețul cu şcoală. $O$ altă categorie de slujbe care impune prezența cântărețului este aceea a ierurgiilor sau a rânduielilor de binecuvântare şi de sfințire din Molitfelnic (precum Sfeştania), care nu au caracter public, ci sunt menite să satisfacă nevoile religioase ale credincioşilor izolați sau ale unui grup social restrâns şi la care cântărețul nu poate fi înlocuit nicidecum de popor.

\section{Cântarea corală bisericească}

Începând din secolul al XVI-lea ediţiile tipărite ale Liturghierelor înlocuiesc termenul de popor cu cel de cor, care, însă, la început, nu avea sensul restrâns pe care i-l atribuim astăzi, când îl aplicăm la cântarea polifonică armonizată. În limbajul liturgic cuvântul cor se referea la acei credincioşi care stăteau împrejurul preotului şi cântau în biserică la unison, dând răspunsurile fiecare de la locul său, fără a avea o instrucție specială şi fără a fi dirijați anume de cântăreți. Altfel spus, în practică, dreptul credincioşilor de a cânta 
la Sfânta Liturghie era exercitat de un grup de credincioşi cu voci mai bune, cu ureche muzicală şi cu mai multă râvnă pentru cântare. Aceştia erau pomeniți la slujbă, ca o categorie sau o grupă aparte, în ultimul aliniat al ecteniei întreite (Încă ne rugăm pentru cei ce aduc daruri..., pentru cei ce se ostenesc şi pentru cei ce cântă....).

Accepțiunea termenului cor s-a schimbat, însă, odată cu apariția cântării armonice. Acest gen de cântare a luat naştere şi s-a dezvoltat în Apus, unde a şi fost pentru prima dată aplicat la liturghie.

Vechea cântare a Bisericii Apusene îşi are începutul tot în psalmodia ebraică şi în muzica de origine greacă a imnelor Bisericii Orientale. După numele Sfântului Ambrozie cel Mare, care a realizat stilizarea muzicii religioase în gen bisericesc şi deosebirea ei de cea profană, această cântare s-a numit mai târziu cântare ambroziană. Spre deosebire de imnele orientale, care erau melodico-ritmice, cântarea ambroziană era metrică, tributară vechiului sistem grecesc. ${ }^{8}$

Sfântul Grigorie cel Mare, episcop al Romei (sfârşitul secolului VI - începutul secolului VII), a organizat cântarea Bisericii din Occident după modelul celei orientale, rezultând astfel aşanumitul cantus planus, firmus, gregorianus romanus sau choralis. Opera muzicală a Sfântului Grigorie cel Mare a fost reunită în cartea cunoscută sub numele de Antifonar, care a fost răspândită în toate bisericile Apusului, prin mijlocirea împăratului Carol cel Mare.

Alături de cântarea monodică gregoriană, a luat naştere mai târziu cântarea pe mai multe voci. Sugestia a venit din domeniul muzicii instrumentale. Mai ales orga a sugerat cântarea armonică, care se va şi numi multă vreme organum, după numele acestui instrument. Cu timpul s-a ajuns să se treacă peste numărul de două voci al organum-ului, ajungându-se astfel la polifonia vocală care va cunoaşte, începând cu secolul al XIV-lea, o mare dezvoltare.

Din Apus, cântarea polifonică a trecut în țările ortodoxe, mai întâi în mediul profan, de unde a fost preluată apoi şi în serviciul

\footnotetext{
${ }^{7}$ Ene Branişte, Temeiuri Biblice şi tradiționale pentru cântarea în comun a credincioşilor, în „Studii Teologice”, nr. 1-2/1954, p. 28.

${ }^{8}$ Petre Vintilescu, op. cit., p. 164.
} 
religios. Astfel, în Rusia, cântarea pe patru voci a fost introdusă încă din prima jumătate a secolului al XVII-lea, pentru prima dată la biserica din Kiev, centrul renaşterii spirituale a Rusiei moderne.

În Biserica Ortodoxă Română cântarea armonică a început să fie întrebuințată după anul 1865, an în care domnitorul Alexandru Ioan Cuza a hotărât introducerea corurilor vocale în bisericile din România. De la această dată şi până în prezent, cântarea corală armonică din țara noastră a cunoscut o continuă dezvoltare şi răspândire.

\section{Corurile bisericești în parohie}

Într-o parohie nu este posibil să fie instruiți în cântarea bisericească toți credincioşii care vin la sfintele slujbe, ci numai o parte dintre ei, de preferință copiii, tinerii şi femeile cu voce şi ureche muzicală mai bună. Aceştia alcătuiesc un cor în accepțiunea mai veche a termenului, adică aceea de grup de credincioşi cu voci mai bune şi ureche muzicală care exercită în practică dreptul comunității de a cânta la Sfânta Liturghie.

Cei care s-au ocupat de problema participării credincioşilor la cântarea liturgică, au avut în vedere şi aspectul cântării corale armonice. Un exemplu grăitor în acest sens este Părintele Gheorghe Şoima. Dânsul încurajează înființarea, acolo unde este posibil, de coruri pe două, trei sau patru voci ${ }^{9}$, dar ține să menționeze: ,decât un cor slab, fie din cauza numărului mic al coriştilor, fie din cauza nepregătirii muzicale a lor sau a dirijorului, mai bine să se cânte omofon". ${ }^{10}$

Chiar şi în bisericile unde există un cor bun, trebuie să răsune, măcar odată la două sau trei Duminici, cântarea bisericească omofonă, executată de toți participanții la slujbă, conduşi vocal de

\footnotetext{
${ }^{9}$ Este vorba de coruri formate din membrii parohiei cântând benevol şi gratuit, din râvnă pentru casa Domnului, căci corurile cu plată nu reprezintă decât o formă de înlocuire a stranei sau a cântărețului, neavând nimic comun cu participarea activă a poporului la Sfânta Liturghie. Cf. Diac. Asist. Ene Branişte, art. cit. , p. 622.

${ }^{10}$ Gheorghe Şoima, Funcțiunile muzicii liturgice, Sibiu, 1945, p. 75.
} 
către corul propriu-zis, care să cânte şi el omofon. Pentru că, spune Părintele Şoima:

„dacă preotul ne îndeamnă: « să zicem toți din tot sufletul»..., cum vom răbda să lăsăm ca numai corul sau un singur cântăreț să răspundă: Doamne miluieşte? Dacă susținem că în biserică corul sau cântărețul răspund preotului în numele tuturor celor prezenți la slujbă, atunci putem deduce că participarea creştinilor la cultul divin nu e necesară, căci în numele lor poate răspunde şi un singur cântăreț, iar enoriaşii se pot ruga în gând acasă. Ori această părere este în contradicție cu învățătura Bisericii". ${ }^{11}$

Cel mai recomandabil este ca cele două modalități de cântare - omofonă şi coral armonică - să alterneze în cadrul aceleiaşi Sfinte Liturghii: imnele cu caracter mai tainic, ca Heruvicul şi Chinonicul, să fie executate de corul propriu-zis, iar cele mai lirice, ca Antifoanele, Sfinte Dumnezeule şi Tatăl nostru, să fie cântate în comun de toți credincioşii. ${ }^{12}$ În această alternanţă stă, după Părintele Şoima, capacitatea muzicii liturgice de a-şi îndeplini toate funcţiile: „Cântarea corală armonică excelează în funcțiile: estetică, pregătitoare şi îndemnătoare la rugăciune, catehetică şi misionară mai ales printre intelectualii indiferenți. La rândul său, muzica bisericească în comun îşi îndeplineşte foarte bine mai ales rolul de vehicul al rugăciunii, apoi rolul de infrățire sufletească, rolul pedagogic şi cel misionar mai ales printre neintelectuali". ${ }^{13}$

În concluzie, se poate spune că, pentru a avea o eficiență misionară cât mai mare, corurile bisericești trebuie să țină seama de necesitățile sufleteşti ale tuturor categoriilor de credincioşi, alternând în repertoriile lor cântările armonice cu cele omofone.

\footnotetext{
${ }^{11}$ Ibidem, p. 76.

${ }^{12}$ Ene Branişte, Participarea la liturghie..., p. 623.

${ }^{13}$ Gheorghe Şoima, op. cit., p. 78.
} 


\section{Sfânta Liturghie în cântare omofonă}

Încă de la instituirea ei, slujba Sfintei Liturghii are caracterul de rugăciune în comun. În pace Domnului să ne rugăm, sau Să zicem toți din tot sufletul şi din tot cugetul... sunt îndemnuri care brăzdează rânduiala Sfintei Liturghii şi care implică participarea tuturor credincioşilor la rugăciune şi cântare.

În anul 1950, Patriarhul Justinian a avut iniţiativa introducerii cântării omofone în bisericile din țara noastră, fiind ferm convins că ,frumoasele cântări bisericeşti constituie unul dintre cele mai rodnice mijloace de întărire a evlaviei şi a legăturilor credincioşilor cu Biserica lor". ${ }^{14}$ În opinia mitropolitului Bartolomeu Anania, această iniţiativă a avut la bază o întreită motivație: extinderea catehizării, consolidarea sentimentului de unitate naţională şi rezistenta împotriva fenomenului sectar. ${ }^{15}$

Între strădaniile Patriarhului Justinian s-a numărat şi aceea de a oferi credincioşilor cărți care să cuprindă cântări bisericești, în primul rând cele de la Sfânta Liturghie. În acest sens, în urma unei hotărâri a Sfântului Sinod din 18 decembrie 1973, s-a tipărit, în anul 1975, un buchet de cântări bisericeşti intitulat Carte de cântări bisericeşti, la care au contribuit Pr. Prof. Ene Branişte şi profesorul şi compozitorul Nicolae Lungu.

După aproape 30 de ani de la apariția acestei Cărți de cântări bisericeşti, Sfântul Sinod al Bisericii Ortodoxe Române, în şedința sa de lucru din 15 iunie 2004, luând în considerare propunerile mitropolitului Bartolomeu Anania pentru reactivarea şi intensificarea cântării omofone în bisericile parohiale, a hotărât reeditarea acestei importante culegeri de cântări bisericeşti. Culegerea a apărut sub titlul Sfânta Liturghie în cântare omofonă, fiind îngrijită de Pr. Prof. Dr. Constantin Drăguşin, directorul Coralei patriarhale.

Această nouă ediție a Cărții de cântări bisericeşti a fost oferită parohiilor, cu nădejdea că ea va contribui ,la intărirea dreptei

${ }^{14}$ Gheorghe Şoima, în „Biserica Ortodoxă Română”, LXX (1952), nr. 6-8, p. 433.

${ }^{15}$ Sfânta Liturghie în cântare omofonă, Bucureşti, Edit. Institutului Biblic şi de Misiune al Bisericii Ortodoxe Române, 2004, p. 3. 
credințe şi a unității sufletești a tuturor fiilor dreptcredincioşi ai Bisericii Ortodoxe Române". ${ }^{16}$

\section{Rolul muzicii la ora de religie}

Dacă ținem cont de rolul important pe care îl are muzica în cultul creştin, atunci nu vom putea concepe o educație religioasă creştină care să fie lipsită de veşmântul sonor al cântării religioase. Ca atare, ora de religie trebuie să devină mediul în care elevii să descopere atât învățătura de credință creştină, cât şi imnografia şi cântarea specifice acesteia.

Există mai multe metode prin care cântarea religioasă poate fi introdusă în cadrul orelor de religie. Menționăm aici trei dintre acestea, pe care le socotim mai reprezentative:

- Învățarea cântărilor religioase după auz

- Corul şcolar

- Auditia

Le vom trata pe rând, încercând să dăm câteva îndrumări metodologice pentru realizarea lor practică.

Învătarea unei cântări religioase după auz este o metodă ce poate fi aplicată cu uşurință oricărei ore de religie. Este recomandabil ca tematica cântării respective să fie în concordanță cu tematica lecției predate în acea oră. Învățarea acestei cântări poate fi realizată fie la începutul orei, caz în care textul cântării devine suport pentru cunoştințele predate ulterior, fie la sfârşitul acesteia, constituindu-se într-o metodă de fixare a cunoştințelor predate.

Pentru realizarea învățării unei cântări religioase după auz profesorul de religie va ține seama de o anumită succesiune logică a momentelor. Mai întâi execută el însuşi cântarea, cerându-le elevilor să asculte cu atenție atât melodia, cât şi textul acesteia. Apoi îi provoacă pe elevi la o discuție care are ca scop scoaterea în evidență a învățăturilor cuprinse în textul cântării respective. Abia apoi se trece la învățarea propriu-zisă, pe fragmente, a cântării.

O altă metodă prin care elevii pot fi apropiați de cântarea religioasă este corul scolar. Profesorul de religie îi poate organiza pe

${ }^{16}$ Ibidem, p. 4. 
elevi într-un cor reprezentativ al şcolii, care să învețe cântări religioase specifice anumitor sărbători (Naşterea Domnului, Învierea Domnului şi altele) sau cântările Sfintei Liturghii. Această activitate se va concretiza fie printr-un concert - de exemplu un concert de colinde la Crăciun -, fie printr-o participare activă la unul dintre serviciile divine din biserică - de pildă executarea răspunsurilor la Sfânta Liturghie.

Cântarea vocală în cadrul corului şcolar diferă de cea efectuată în cadrul orelor de religie pentru că abordează un repertoriu mai variat de cântări. Cântarea corală se poate efectua fie omofon cu ison, dacă linia melodică permite -, fie acolo unde este posibil, pe două, trei sau patru voci.

Corul şcolii, în mod firesc, trebuie să cuprindă întreaga comunitate de elevi, pentru a se bucura cu toții de avantajele pe care le oferă cântarea corală, atât din punct de vedere al dezvoltării lor muzicale, cât şi din punct de vedere al cultivării înaltelor sentimente morale şi estetice.

Auditia constituie una dintre cele mai eficiente activități muzicale, prin mijlocirea căreia elevii, de la cele mai mici vârste şcolare iau contact direct cu cântarea bisericească. Pentru ca audiția muzicală a cântărilor să captiveze atenția şi interesul elevilor, este necesar ca acestea să corespundă specificului de vârstă al ascultătorilor.

Din punct de vedere didactic, orice fel de audiție muzicală trebuie să fie bine pregătită printr-o prealabilă prezentare a pieselor muzicale destinate audierii. Se va preciza cine este autorul textului, al melodiei, ce loc ocupă în cult cântarea respectivă. De asemenea, se vor extrage învățăturile dogmatice şi morale cuprinse în textul cântării. Profesorul va atrage atenția elevilor asupra corespondenței ce există între muzică şi text.

Scopul esențial al audițiilor muzicale trebuie să fie acela de a dezvolta dragostea elevilor pentru adevăratele valori artistice muzicale şi de a ilustra diverse teme teoretice din programa şcolară. ${ }^{17}$

\footnotetext{
17 Ana Motora-Ionescu, Anton Dogaru, Indrumări metodice pentru predarea muzicii, Bucureşti, Edit. Didactică şi Pedagogică, 1983, p. 180.
} 
Iată doar câteva dintre metodele prin care muzica religioasă poate contribui la o mai mare apropiere a elevilor de ora de religie. Utilizarea acestui gen muzical în procesul didactic este cu atât mai justificată, dacă ținem seama că în Ortodoxie credința nu este doar mărturisită teoretic, ci este celebrată. Or, celebrarea credinței se face mai ales prin imnografia şi cântarea bisericească.

\section{Concluzii}

Mărturiile istoriei şi ale tradiţiei în favoarea cântării în comun a credincioşilor în biserică sunt prea numeroase şi prea categorice pentru ca să mai pună cineva în discuție canonicitatea sau legitimitatea ei. Într-o formă sau alta, într-o măsură mai mare sau mai mică, credincioşii au luat parte la cântarea bisericească din timpul sfintelor slujbe, această practică constituind o tradiție veche şi un principiu perfect ortodox, a cărui aplicare practică a variat după vremuri şi împrejurări, dar care $n$-a fost niciodată desfiinţat sau anulat. Anumite practici mai noi, precum cântarea corală armonică, nu pot face altceva decât să se integreze în această tradiție, contribuind la intensificarea participării credincioşilor la cultul divin public. Acelaşi scop îl are şi ora de religie, care îi ajută pe tineri, prin toate activitățile pe care le conține - inclusiv cele muzicale, să se integreze cât mai deplin în atmosfera comuniunii liturgice.

\section{Bibliografie:}

1. Antim, Târgovişteanul, Despre cântarea credincioşilor în bisericăa în „Biserica Ortodoxă Română”, LXXI (1953), nr. 11-12.

2. Branişte, Ene, Participarea la liturghie şi metodele pentru realizarea $e i$, în ,Studii Teologice”, nr. 7-8/1949.

3. Idem, Temeiuri Biblice şi tradiționale pentru cântarea în comun a credincioşilor, în „Studii Teologice”, nr. 1-2/1954.

4. Lungu, Nicolae, Cântarea în comun a poporului în biserică, în „Studii Teologice", III (1951), nr. 1-2.

5. Motora-Ionescu, Ana, Dogaru, Anton, Indrumări metodice pentru predarea muzicii, Bucureşti, Edit. Didactică şi Pedagogică, 1983.

6. Necula, Nicolae D., Tradiție şi înnoire în slujirea liturgică, Galaţi, Edit. Episcopiei Dunării de Jos, 1996.

7. Şoima, Gheorghe, Funcțiunile muzicii liturgice, Sibiu, 1945. 
8. Vintilescu, Petre, Despre poezia imnografică din cărțile de ritual şi cântarea bisericească, ediția a II-a, Cluj-Napoca, Edit. Renaşterea, 2005. 9. *** „Biserica ortodoxă Română”, LXX (1952), nr. 6-8.

10. *** Sfânta Liturghie în cântare omofonă, Bucureşti, Edit. Institutului Biblic şi de Misiune al Bisericii Ortodoxe Române, 2004. 